\title{
Gastrointestinal microorganisms in cats and dogs: a brief review
}

\author{
Microorganismos gastrointestinales en gatos y perros: una revisión breve
}

\author{
JF Garcia-Mazcorro ${ }^{a^{*}}$, Y Minamoto ${ }^{\mathrm{b}}$ \\ ${ }^{a}$ Facultad de Medicina Veterinaria y Zootecnia, Universidad Autónoma de Nuevo León, Nuevo León, México. \\ ${ }^{\mathrm{b}}$ Gastrointestinal Laboratory, Department of Small Animal Clinical Sciences, Texas A\&M University, Texas, USA.
}

\begin{abstract}
RESUMEN
El tracto gastrointestinal (GI) de animales contiene diferentes tipos de microorganismos conocido como la microbiota GI. Por mucho tiempo, la microbiota GI ha generado interés porque los microorganismos GI están involucrados en múltiples procesos fisiológicos en el hospedero, así perpetuando salud o enfermedad. Estudios recientes han demostrado que la microbiota GI de gatos y perros es tan compleja como en humanos y otros animales, revelado con el uso de tecnologías de secuencia modernas y otras técnicas moleculares. La microbiota GI incluye miembros de todos los tres dominios principales de vida (Archaea, Bacterias y Eucariotas), pero las bacterias son el grupo de microorganismos más abundante y metabólicamente activo. El estómago de gatos y perros esta principalmente poblado de Helicobacter spp., el cual en perros puede representar tanto como el $98 \%$ de toda la microbiota bacteriana en el estómago. El intestino delgado contiene una microbiota más diversa, conteniendo representantes de al menos cinco diferentes filos bacterianos (principalmente Firmicutes y Bacteroidetes). El intestino grueso contiene el grupo de bacterias más abundante $\left(\sim 10^{11}\right.$ células bacterianas por gramo de contenido intestinal), diverso (al menos diez diferentes filos han sido detectados) y metabólicamente relevante en el tracto GI. La mayoría de las bacterias en el intestino grueso son anaerobios estrictos, los cuales dependen de la fermentación de sustancias no digeridas para subsistir. Aunque estudios recientes han dilucidado las complejidades de la microbiota GI en gatos y perros, más investigación todavía es necesaria para encontrar maneras de manipular exitosamente los microorganismos GI para prevenir y/o tratar enfermedades GI.
\end{abstract}

Palabras clave: gastrointestinal, microbiota, gatos, perros.

\section{SUMMARY}

The gastrointestinal (GI) tract of animals contains different types of microorganisms known as the GI microbiota. The GI microbiota has long been of interest because of its involvement in multiple physiological processes in the host, influencing health or disease. Recent studies have shown that the GI microbiota of cats and dogs is as complex as the one present in humans and other animals, according to state-of-the-art sequencing technologies and other molecular techniques. The GI microbiota includes members of all three main life domains (Archaea, Bacteria, and Eukaryotes), with bacteria being the most abundant and metabolically active group of microorganisms. The stomach of cats and dogs is mainly inhabited by Helicobacter spp., which in dogs may account for as much as $98 \%$ of all gastric bacterial microbiota. The small intestine harbors a more diverse microbiota as it contains representatives from at least five bacterial phyla (mainly Firmicutes and Bacteroidetes). The large intestine harbors the most abundant $\left(\sim 10^{11}\right.$ bacterial cells per gram of intestinal content), diverse (at least 10 bacterial phyla have been identified) and physiologically relevant group of bacteria in the GI tract. Most bacteria in the large intestine are strict anaerobes that depend on fermentation of non-digested dietary substances to subsist. Although recent studies are shedding light into the complexity of the GI microbiota in cats and dogs, further research is needed to find ways to successfully manipulate GI microorganisms to prevent and/or treat GI diseases.

Key words: gastrointestinal, microbiota, cats, dogs.

\section{INTRODUCTION}

The gastrointestinal (GI) tract of animals is colonised by a dense and heterogeneous group of microorganisms known as the GI microbiota, which supply more than nine million unique genes to the gene repertoire in the eukaryotic host (Yang et al 2009). The GI microbiota has long been of interest because of its involvement in multiple physiological processes in the host, including

Accepted: 10.01.2013.

* Francisco Villa s/n Col. Ex-Hacienda El Canadá C.P. 66050, Gral. Escobedo, Nuevo León, México; josegarcia_mex@hotmail.com resistance against colonization by pathogens (Stecher and Hardt 2011), production of useful substances that act as energy source for intestinal epithelial cells (Louis and Flint 2009), modulation of the intestinal immune system (Hooper and Macpherson 2010), salvage of energy from undigested dietary components (Cummings and Macfarlane 1997), and stimulation of intestinal angiogenesis (Stappenbeck et al 2002).

Most of the current information about the composition and activity of the GI microbiota comes from studies in human populations. However, an increasing number of investigations have also studied intestinal microbes in other animals, especially cats and dogs (Suchodolski 2011). This review summarises current information 
about the GI microbiota with emphasis on the GI bacterial microbiota of cats and dogs.

\section{THE GI MICROBIOTA}

The GI tract of animals is one of the most complex microbial ecosystems on Earth, and it is continuously affected by factors associated with the host (Spor et al 2011, Van den Abbeele et al 2011) and the outside environment (Claesson et al 2012). This complexity has been an obstacle to study single independent factors associated with its changes over time and among different populations of animals (e.g., healthy and diseased). Also, it is often difficult to determine the nature of the interactions among the microorganisms during health or disease, although recent advances in mathematical modeling could help understand this phenomenon (Hellweger and Bucci 2009, Arciero et al 2010). Moreover, there are controversies with regards to the way we classify microbial species (Staley 2006, Schleifer 2009). Despite this complexity, there is a growing body of literature suggesting that the GI microbiota can be studied objectively, and that health could be enhanced in the host through manipulation of its constitutive intestinal microbial populations.

\section{CHARACTERIZATION OF THE GI MICROBIOTA}

\section{CULTURE METHODS}

The characterization of the GI microbiota is the first step in determining its role in health or disease. Classic culture methods have the advantages of being relatively inexpensive, widely available, and suitable for biochemical and physiological studies, and therefore have been extensively used to characterise the GI microbiota of cats and dogs (see below). However, the usefulness of culture techniques to characterise microorganisms in the gut and elsewhere has long been questioned because it is not representative enough regarding both enumeration and community structure (Ritz 2007). While experts generally agree that about $99 \%$ of all GI microorganisms have not been successfully cultured (Tap et al 2009), a recent article showed that about $70 \%$ of all fecal bacterial genera (as determined by pyrosequencing) could be successfully cultured using an in-house culture media containing a mixture of several commercially available ingredients (Goodman et al 2011). Modifications to this universal gut microbiota media will facilitate the culture of more intestinal microorganisms and make possible a correlation between microbial abundance and utilization of dietary substances.

\section{MOLECULAR METHODS}

In contrast to culture methods, which rely on the identification of GI microorganisms by means of a phenoty- pic characterization, molecular methodologies aim to identify and categorise microorganisms by means of detecting specific molecules inside the cells (e.g., DNA or RNA) (Zuckerkandl and Pauling 1965). The 16S rRNA gene has often been used to identify bacteria because it is universally distributed and appears to have undergone a relatively slow change in base pair composition throughout evolution (Fox et al 1980). In other words, the 16S rRNA gene contains conserved regions (same among all bacteria) as well as variable and highly variable regions that allow the distinction and classification of bacterial phylotypes, according to theories of molecular evolution (Lemey et al 2009). Some examples of methodological differences between culture-based and culture-independent approaches include survey depth (tens to hundreds of cultural isolates versus thousands to millions of $16 \mathrm{~S}$ rRNA gene sequences), accuracy of bacterial 16S rRNA gene assignments, and documentation of the generated data (Goodman et al 2011). A summary of the most commonly used methods and techniques to study the gastrointestinal microbiota is presented in table 1.

Polymerase chain reaction (PCR). PCR is a common and often indispensable molecular technique to characterize the GI microbiota. Currently, PCR is performed using a heat-stable DNA polymerase which can generate millions of copies of a given target sequence (e.g., a 16S rRNA gene fragment) in one hour or less. Some sequencing techniques require the use of PCR for generating amplicons (i.e., DNA fragments amplified by PCR). It is important to note that all PCR-based techniques suffer from several biases, including the fact that the generated $16 \mathrm{~S}$ rRNA gene copies cannot be accurately extrapolated to the number of the microorganisms themselves, in part because different bacteria have different number of copies of this gene even within the same species (Acinas et al 2004, Lee et al 2008). Interestingly, these differences in the number of copies of the $16 \mathrm{~S}$ rRNA gene may reflect ecological strategies of bacteria in respond to resource availability (Klappenbach et al 2000).

Fingerprinting methods. The obtained 16S rRNA gene amplicons (e.g., from intestinal contents) are often the same size in number of base pairs, and therefore would appear as a single band in an agarose or polyacrylamide gel. However, these amplicons are likely to differ from one another in their base pair composition. When exposed to a denaturing agent or to increasing temperatures, these differences in base pair composition make the amplicons migrate at a different speed throughout a gel matrix. Denaturing Gradient Gel Electrophoresis (DGGE) and Temperature Gradient Gel Electrophoresis (TGGE) are examples of molecular fingerprinting methods that separate amplicons based on this principle. In particular, DGGE has been shown to be useful to assess qualitative variations in the GI microbiota of dogs among different 


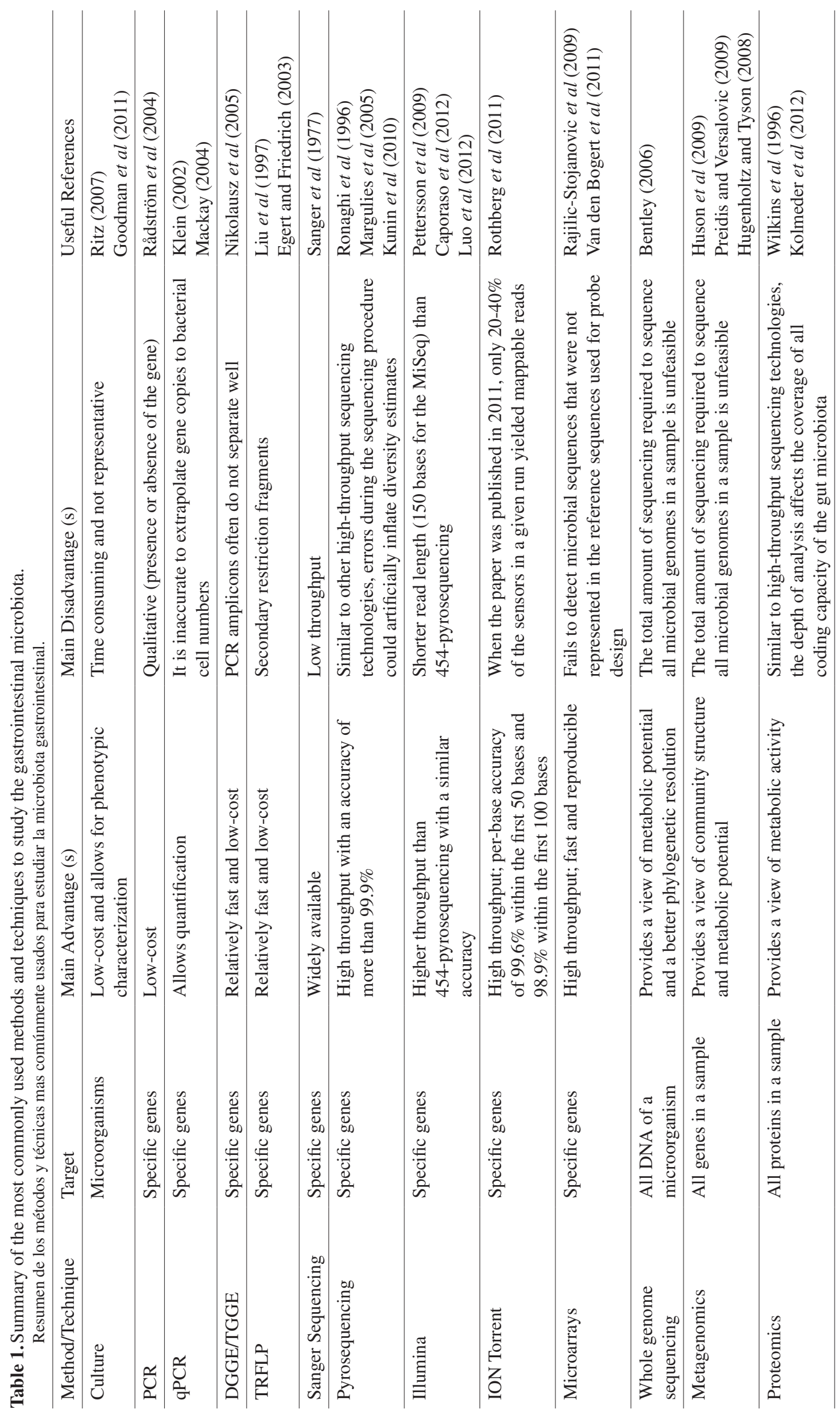


compartments of the intestinal tract (Suchodolski et al 2005). The result of DGGE or TGGE analysis is a specific banding pattern for every sample analysed, therefore providing a qualitative view of the microbial composition of the sample. However, fingerprinting techniques are not very useful to characterise microbial ecosystems because they often fail to accurately separate $16 \mathrm{~S}$ rRNA gene fragments (Jackson et al 2000, Nikolausz et al 2005), thus underestimating the true bacterial diversity and its changes against external perturbations.

Quantitative real-time PCR ( $q P C R)$. In conventional $\mathrm{PCR}$, the amplicons are routinely detected using electrophoresis on agarose gels after the PCR has finished. Because of this, traditional PCR is not capable of quantifying the genomic targets; it only provides information about the presence (band in the gel) or absence (no band in the gel) of the target. In contrast, PCR has been adapted to also allow the quantification of the unknown genomic targets as the PCR progresses (in real-time). This is possible by including in the PCR reaction a fluorescent molecule that reports an increase in the amount of DNA with a proportional increase in fluorescent signal. The fluorescent chemistries employed for this purpose include DNAbinding dyes and fluorescently-labeled sequence-specific primers or probes. qPCR has been widely used to assess the effect of different treatments on the abundance of the GI microbiota in cats and dogs (Gronvold et al 2010, Garcia-Mazcorro et al 2011) as well as in humans (Malinen et al 2005, Larsen et al 2011). However, bacterial cell numbers cannot directly be estimated from qPCR data in part because the cellular genome content varies with the growth phase of the organisms and bacteria have different number of copies of the 16S rRNA gene (see PCR above).

Fluorescence in situ hybridization (FISH). The detection of bacterial genomic targets using qPCR is useful when evaluating changes in the quantitative abundance of the microbiota, for example during administration of probiotics or therapeutic agents. However, the accurate extrapolation from amplified genomic targets to the actual numbers of bacterial cells is often difficult, mainly because bacteria have different copy numbers of the $16 \mathrm{~S}$ rRNA gene. Unlike qPCR, FISH is capable of quantifying the actual bacterial cells by direct labeling of the $16 \mathrm{~S}$ rRNA using fluorescently-labeled oligonucleotides. The FISH technique takes advantage of the fact that each bacterium usually contains thousands of ribosomes spread throughout the cell. Theoretically, like in PCR, it is possible to develop oligonucleotides that are capable to detect microorganisms at all taxonomic levels (i.e., Phylum, Class, Order, Family, Genus). However, this is often challenging due to high similarities in the 16S rRNA gene composition among phylogenetically related microorganisms. FISH can also provide important information about the morphology and spatial distribution of microorganisms in the GI tract (Simpson et al 2006).
Sequencing technologies. The identity of each 16S rRNA gene amplicon can be determined by estimating the order of the base pairs (sequencing). This has been traditionally done using nucleotides base analogs (dideoxynucleotides) that lack the 3'-hydroxil group essential in phosphodiester bond formation, which act as specific chain-terminating inhibitors of DNA polymerase (Sanger et al 1977). This Sanger method is still used routinely in many laboratories for sequencing low number of samples. However, complex microbial ecosystems such as the intestinal tract contain millions of microorganisms, which makes necessary to clone and sequence thousands of individual PCR amplicons in order to obtain a representative view of the microbial composition. Recently developed high-throughput techniques such as 454-pyrosequencing (Margulies et al 2005) are capable of sequencing millions of base pairs in one hour or less, and have shown to be useful to study the feline and canine GI microbiota (Suchodolski et al 2009, Middelbos et al 2010, Garcia-Mazcorro et al 2011, Handl et al 2011). Other high-throughput techniques are based on different principles (e.g., reverse termination) and are discussed elsewhere (Pettersson et al 2009). Interestingly, a nonoptical genome sequencing has been developed (Rothberg et al 2011), which promises a better performance than traditional optical-based sequencing. Nonetheless, the cost and necessary expertise for both sequencing and after-sequencing analysis procedures make most of these techniques inaccessible for many scientists around the globe. Fortunately, a number of freely available software platforms have been developed such as QIIME (Quantitative Insights into Microbial Ecology ${ }^{1}$ ), which is capable of analyzing thousands of sequences in short periods of time. QIIME also offers free comprehensive guides for beginners as well as expert advice for more advanced users.

\section{THE COMPOSITION OF THE GI MICROBIOTA}

The composition and metabolic activity of the GI microbiota varies along the GI tract, in part reflecting anatomical and physiological conditions inherent to each of the intestinal sections. In cats and dogs, as well as in other monogastric animals, both the bacterial diversity (an index that incorporates the number of species in an area and their relative abundance) and richness (number of species) are higher in the large intestine when compared to the stomach and all regions of the small intestine (Ritchie et al 2008, Suchodolski et al 2008). The GI microbiota includes all three major domains of life (Archaea, Bacteria, and Eukaryotes), but bacteria make up the most abundant and metabolically active group of microorganisms in the GI tract. For example, a recent metagenomic study showed that bacteria may represent as much as $98 \%$ of all fecal microbiota in dogs, with Archaea, Eukaryotes, and viruses representing only

http://www.qiime.org/ 
about 2\% (Swanson et al 2011). Similarly, a recent study also used a metagenomic approach and showed that Eukaryotes, Archaea, and viruses were minor constituents $(<3 \%)$ of the fecal microbiota in cats, while bacteria represented the great majority (97.8\%) (Tun et al 2012).

In monogastric animals, the large intestine contains the most abundant, diverse and metabolically relevant group of bacteria in the GI tract. The large intestine contains bacterial groups mainly within the phyla Firmicutes and Bacteroidetes. Other phyla such as Actinobacteria, Proteobacteria, Fusobacteria, Spirochaetes, Verrucomicrobia, Cyanobacteria, and Tenericutes are also frequently identified but their proportions are usually low. However, the exact proportions of each bacterial group vary widely throughout the literature. For example, one study showed that healthy cats and dogs may harbor $>90 \%$ of Firmicutes in faeces (Handl et al 2011), while others have shown that these animal species may only harbor $\sim 13 \%$ (cats) and $\sim 35 \%$ (dogs) of this phylum also in faeces (Swanson et al 2011, Tun et al 2012). The reasons for these discrepancies (see below) are unknown but may include differences in DNA extraction protocols (Zoetendal et al 2001), intra-stool variability of intestinal microorganisms (Garcia-Mazcorro et al 2009), inter-individual differences (Handl et al 2011), the target region of the
16S rRNA gene (Baker et al 2003), as well as inherent differences among the techniques utilized to characterize the microbiota (Zoetendal et al 2004, Kunin et al 2010).

Early culture-based studies suggested that the distal part of the human intestinal tract may harbor about 300 different bacterial species (Moore and Holdeman 1975, Savage 1977). However, recent culture-independent studies suggest that on average humans have an estimated richness of 943 bacterial species (operational taxonomic units or OTUs at $98 \%$ similarity) in faeces per subject (Tap et al 2009). In contrast, one study suggested that cats and dogs may harbor only 60 (cats) and 39 (dogs) OTUs (97\% similarity) in faeces per subject (Handl et al 2011). This agrees with other studies that showed the presence of only 84 and 52 OTUs in the colon of cats and dogs based on a $98 \%$ similarity criterion (Ritchie et al 2008, Suchodolski et al 2008).

\section{THE GI MICROBIOTA OF CATS AND DOGS}

An overview of some of the most relevant investigations of the GI microbiota in cats and dogs is presented in table 2. Among all regions of the GI tract of these and other animal species, the distal part of the intestinal tract (i.e. fecal microbiota) has been the most widely studied to date (figure 1), mainly because of the ease of sampling.
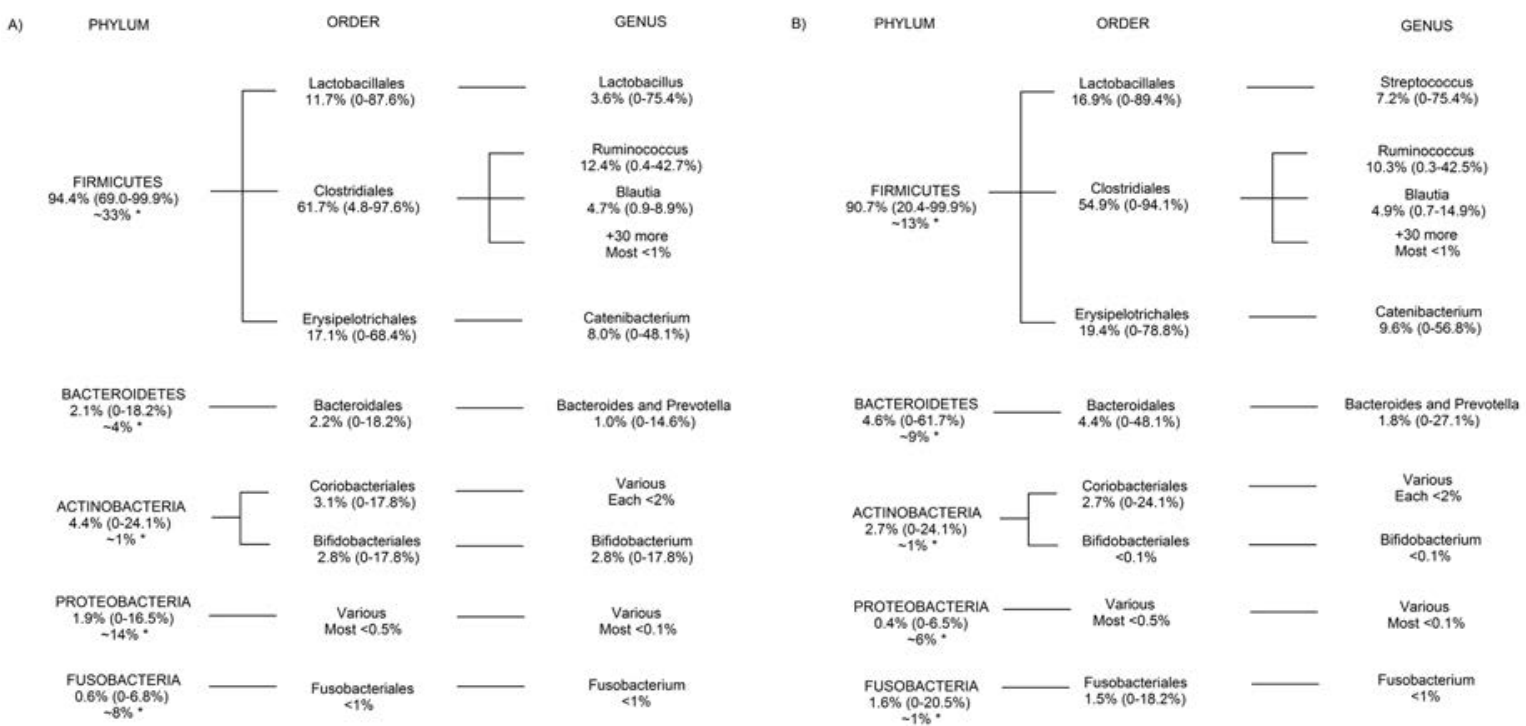

Figure 1. Simplified view of the faecal bacterial composition of dogs (A, left) and cats (B, right) at phylum, order and genus level. Numbers represent the average (minimum-maximum) of the relative proportions of sequences (number of sequences obtained from the bacterial group divided by the total number of sequences obtained), calculated according to both a published (Garcia-Mazcorro et al 2011, 12 dogs and 12 cats) and an unpublished (Weber et al 10 dogs and 10 cats) study using 454-pyrosequencing with the same primer set. Clostridium was the most abundant genus in both cats and dogs ( $>20 \%$ on average in both studies) but it does not appear in this figure due to uncertain taxonomic classification. At the phylum level, we also included the approximate estimates $(*)$ published by Swanson et al (2011) and Tun et al (2012) using a metagenomics approach (please see main text for more details).

Visión simplificada de la composición bacteriana fecal en perros (A, izquierda) y gatos (B, derecha) al nivel de filo, orden y género. Los números son promedios (mínimo-máximo) de proporciones relativas de secuencias (número de secuencias obtenidas del grupo bacteriano dividido entre el número total de secuencias obtenidas) calculado de un estudio publicado (García-Mazcorro et al 2011, 12 perros y 12 gatos) y un estudio no publicado (Weber et al 10 perros y 10 gatos) usando 454-pirosecuenciacion con el mismo par de oligonucleótidos. Clostridium fue el género más abundante en gatos y perros ( $>20 \%$ en promedio en ambos estudios) pero fue omitido en esta figura debido a clasificación taxonómica incierta. Al nivel de filo, también se incluyeron los estimados aproximados (*) publicados por Swanson et al (2011) y Tun et al (2012) usando un método metagenómico (ver texto para más detalles). 


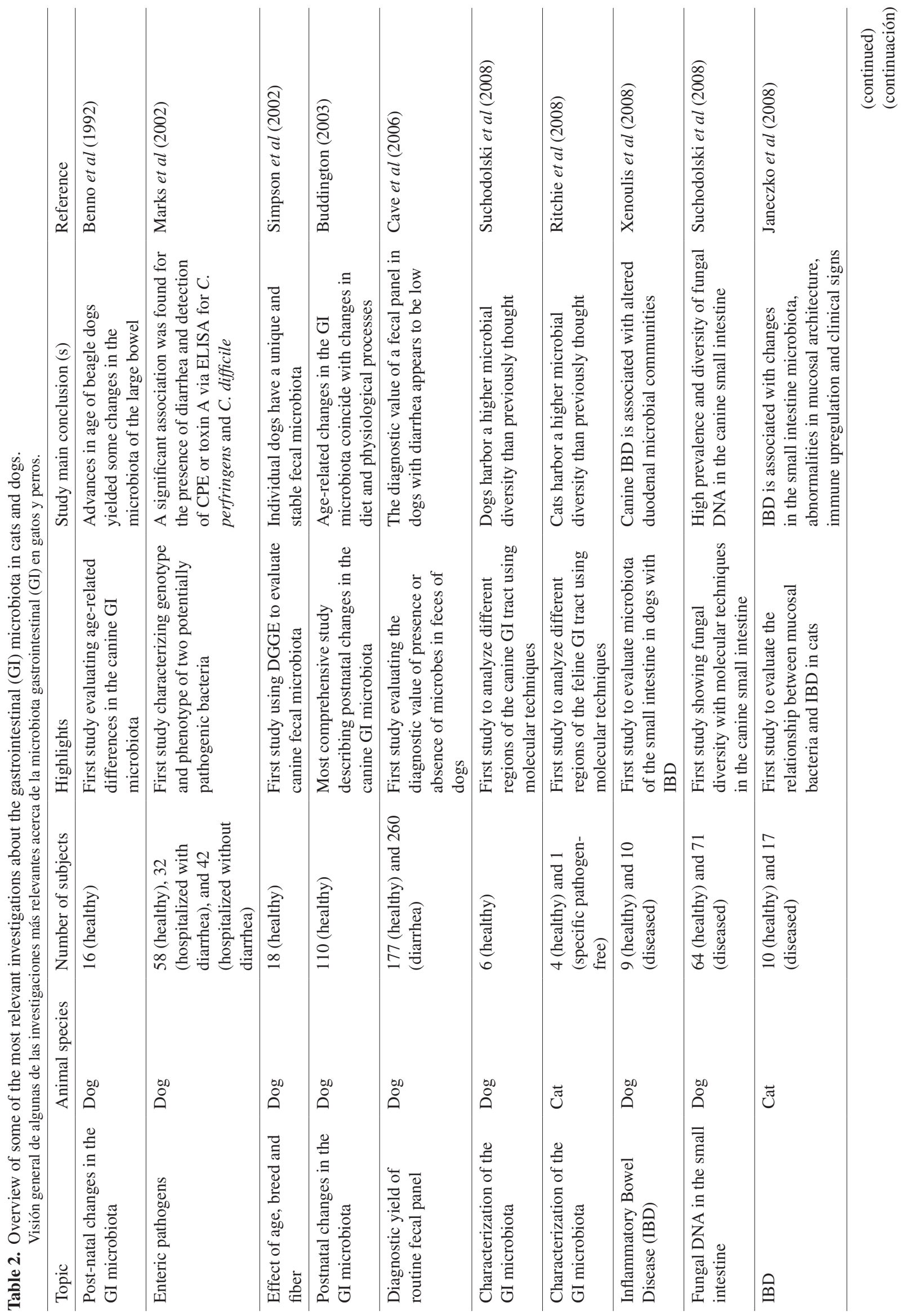




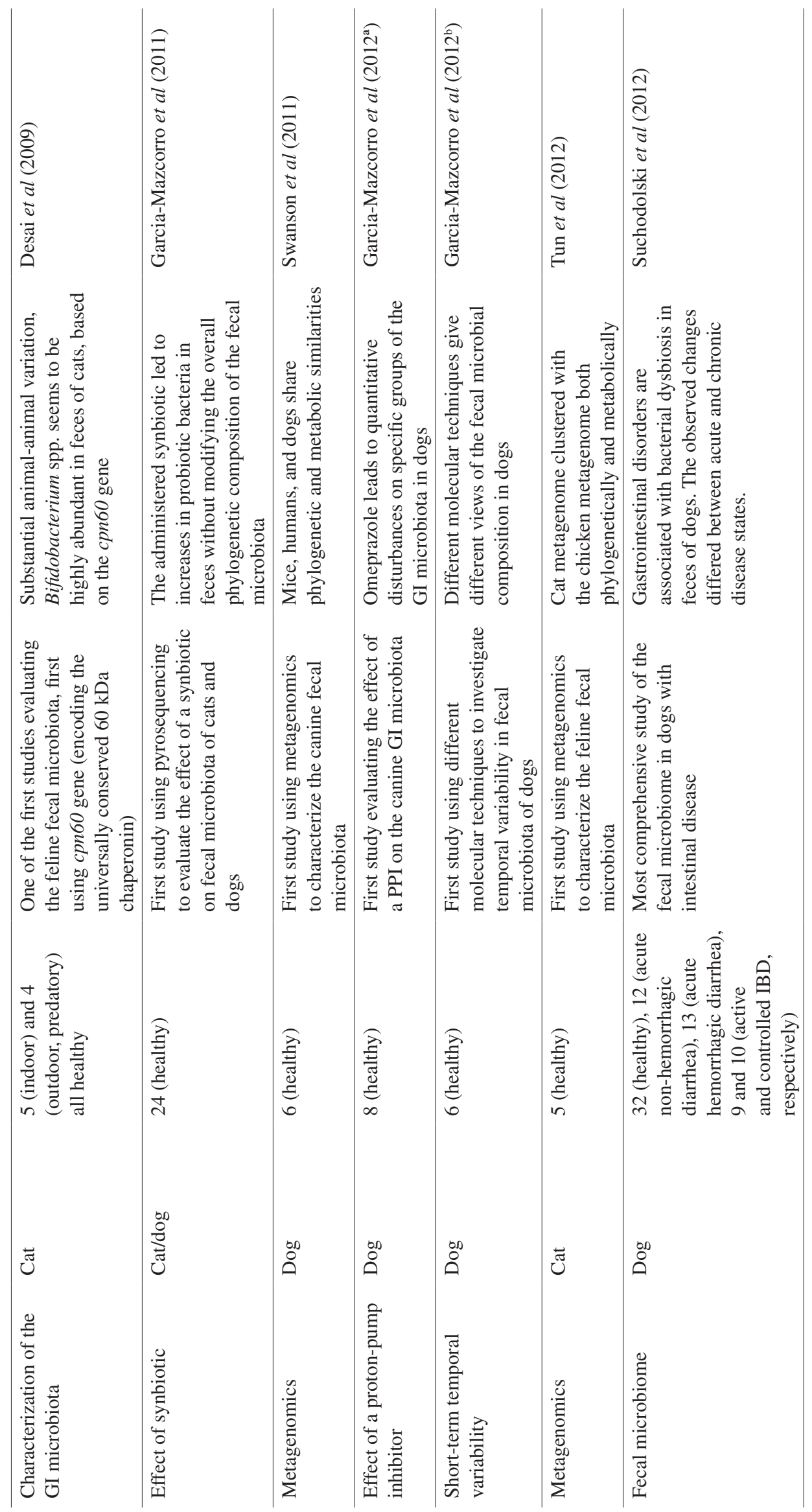


It is important to keep in mind that there are important differences in the reported abundances of GI microorganisms among different studies. This may be due to the DNA extraction method employed as well as the number of copies and the target region within the 16S rRNA gene (see above). A good example of these discrepancies is the recent summary of Armougom and Raoult (2008) about Firmicutes and Bacteroidetes in humans and mice.

\section{THE GI MICROBIOTA OF CATS}

Stomach. The stomach of animals was traditionally thought to lack a complex microbial ecosystem. This belief was sustained in part by the observation that gastric acid kills several microorganisms instantly (Giannella et al 1972). However, culture-independent molecular techniques are revealing a different story. An early study used several detection techniques and showed that the stomach of $91 \%$ of pet cats $(n=58)$ were positive for the genus Helicobacter (Neiger et al 1998), suggesting a high occurrence of this bacterial group in the feline stomach. In another study, it was shown that cats and dogs are predominantly coloniszed by $H$. heilmannii (Priestnall et al 2004) but other species (e.g., H. felis, H. bizzozeronii, $H$. salomonis, $H$. pametensis) have also been identified in these animal species (Neiger and Simpson 2000).

Small intestine. Osbaldiston and Stowe (1971) were among the first to investigate the composition of the GI microbiota in cats $(\mathrm{n}=12)$ using a wide variety of culture media. In this study, coliforms, Streptococcus, Enterococcus, and Lactobacillus were the predominant groups of bacteria along the feline GI tract. Other earlier studies suggested that Bacteroides and Clostridium spp. were the most common bacteria in the duodenum of cats (Papasouliotis et al 1998, Johnston et al 2001), also based on cultural isolates. Similarly, a recent study used molecular techniques and suggested that the small intestine (i.e., jejunum) of cats harbors mainly the orders Clostridiales and Lactobacillales $(\sim 90 \%)$ but also small proportions of at least five more orders, while the ileum and the colon both harbored a high proportion ( $>50 \%$ ) of Clostridiales with low proportions of Actinobacteria ( 5\%) (Ritchie et al 2008).

Large intestine. A recent study sequenced the gene encoding the universal $60 \mathrm{kDa}$ chaperonin and showed that the faecal microbiota of cats was dominated by Actinobacteria $(\sim 53 \%)$ and Firmicutes ( 40\%) (Desai et al 2009). Recent studies using 454-pyrosequencing suggest that $>$ $90 \%$ of all sequences obtained from feces of healthy cats belong to the Phylum Firmicutes (Garcia-Mazcorro et al 2011, Handl et al 2011), especially members of the family Clostridiaceae, while a metagenomic study suggests that Bacteroidetes/Chlorobi is the most abundant bacterial group $(\sim 68 \%)$, followed by Firmicutes $(\sim 13 \%)$ and
Proteobacteria $(\sim 6 \%)$ also in faeces of cats (Tun et al 2012). However, it is important to point out that the study by Tun et al also reports that Bacteroidetes only represented $\sim 9 \%$ of the obtained sequence reads, while the phyla Chlorobi and Chloroflexi represented less than $1 \%$ of the reads. Thus, it is not clear which group represented the remaining $\sim 59 \%$ of difference between the reported percentage of the Bacteroidetes/Chlorobi group ( 68\%) and the reported percentage of Bacteroidetes alone ( $9 \%$ ). We speculate that these discrepancies in the reported percentages may be due in part to the pipeline used to assign taxonomies.

In part because most GI microorganisms have not been successfully cultured, little is known about the phenotype of the GI microbiota in cats. The three major short-chain fatty acids (SCFA) found in cats are butyrate, acetate, and propionate (Brosey et al 2000). In particular, butyrate is considered to play a vital role in colonic human health (Hamer et al 2008, Louis and Flint, 2009) but little is known about its role in intestinal health of cats. Nonetheless, butyrate-producing bacteria are commonly found in feces of cats (Handl et al 2011).

\section{THE GI MICROBIOTA OF DOGS}

Stomach. A study published last year showed that the stomach of healthy dogs is home of a diverse microbiota (at least 4 phyla were identified), as evaluated by 454-pyrosequencing (Garcia-Mazcorro et al 2012a). Despite this diversity, one single genus (i.e., Helicobacter) was by far the most predominant ( 98\% of all gastric microbiota). These results are in accordance with one study that showed that the human stomach is also home of a diverse microbiota, although the genus Helicobacter ( $H$. pylori only) constituted only $42 \%$ of all sequences analyzed (Bik et al 2006).

Small intestine. Clapper and Meade (1963) attempted one of the first characterizations of bacteria and fungi in the lower intestinal tract of dogs using twelve different types of culture media. Using rectal swabs from 25 healthy Beagle dogs, the authors isolated 20 species of bacteria and 10 species of fungi (Clapper and Meade 1963). More recent studies using molecular techniques have shown the presence of at least four different bacterial phyla in the intestinal tract of dogs, namely Firmicutes (47.7\%), Proteobacteria (23.3\%), Fusobacteria (16.6\%), and Bacteroidetes (16.6\%) (Suchodolski et al 2008). Interestingly, these proportions differed depending on the intestinal compartment analyzed, with duodenum and jejunum containing more than 50\% Firmicutes, while the ileum and colon only harbored $~ 30 \%$ of this phylum (Suchodolski et al 2008). Still, a more recent study used 454-pyrosequencing and identified ten bacterial phyla in the jejunum of dogs (Suchodolski et al 2009), although more than half of these groups were 
only found in very low proportions $(<1 \%$ of all microbiota). A recent article used FISH to quantify bacteria in the duodenal biopsies of dogs and found a median of zero bacteria (range: 0-3) per microscopic field using almost 1000 microscopic fields (Garcia-Mazcorro et al 2012 $)$. In contrast, the same article found a high bacterial diversity (median: 173 OTUs) using 454-pyrosequencing also in duodenal biopsies from the same dogs. The reasons for this discrepancy are unknown but it may relate to the destruction of intestinal mucus during formalin fixation of the biopsies before paraffin embedding.

Large intestine. Some studies suggest that, in faeces, Firmicutes represent the great majority $(>90 \%)$ of the faecal microbiota in dogs (Garcia-Mazcorro et al 2011, Handl et al 2011). On the other hand, a recent metagenomic study suggested that the Bacteroidetes/Chlorobi group and Firmicutes were the dominant bacterial phyla $(\sim 35 \%)$, followed by Proteobacteria $(\sim 15 \%)$ and Fusobacteria $(\sim 8 \%)$ also in faeces of dogs (Swanson et al 2011). However, the results of this study show, just as in the reports of Tun et al, that Bacteroidetes only represented $\sim 3 \%$ of all the obtained reads, while the Chloroflexi and the Chlorobi groups represented less than $1 \%$ of the reads. Therefore, it is not clear which group represented the difference between the reported percentage of the Bacteroidetes/Chlorobi group $(\sim 35 \%)$ and the percentage of Bacteroidetes alone $(\sim 3 \%)$. It is possible that the remaining percentage represents unclassified members of Bacteroidetes, but this has been scarcely discussed in the available literature.

As mentioned above, little is known about the phenotype of GI microorganisms in cats and dogs. As in cats, the major SCFA in dogs are butyrate, acetate, and propionate (Swanson et al 2002). A butyrate-producer bacterium that has attracted much attention for its role in intestinal health of humans is Faecalibacterium prausnitzii (Sokol et al 2009). A recent article suggests that Faecalibacterium-relatives are also abundant in faeces of dogs (Garcia-Mazcorro et al 2012 ), although it has been suggested that canine Faecalibacterium spp. may not be $F$. prausnitzii, based on phylogenetic analysis of near-full-length 16S rRNA gene sequences belonging to a canine clone and a human strain (Suchodolski et al 2008). Other butyrate-producers bacteria such as Eubacterium and Roseburia have been found in dogs and cats (Handl et al 2011).

\section{MANIPULATION OF THE GI MICROBIOTA}

Acknowledging that GI microbiota is closely involved in the wellbeing of the host led to the idea of manipulating intestinal microorganisms to enhance health. Several approaches have been used to accomplish this goal in cats and dogs (see below). In contrast, the consumption of therapeutic agents such as antibiotics can also lead to unintended modifications of the GI microbiota, although less research on this topic is available in cats and dogs.

\section{PROBIOTICS AND PREBIOTICS}

Probiotics can be defined as live microorganisms that, if consumed in adequate amounts, would provide a health benefit to the host (FAO/WHO, 2002). On the other hand, prebiotics are selectively fermented ingredients that cause specific changes in the composition and/or activity of the gastrointestinal microbiota (Gibson et al 2010), thus also conferring health benefits on the host, while synbiotics are preparations containing both probiotics and prebiotics.

Sunvold et al (1995) were among the first to evaluate the in vitro effect of a prebiotic on faecal fermentation patterns of cats and dogs. In this study, the addition of fiber (citrus pulp) led to a higher organic matter disappearance and lower acetate to propionate ratio in both dogs and cats; however, these changes were not correlated with modification of the faecal microbiota. While other studies have also researched the properties and effects of probiotics and prebiotics on the composition and/or activity of the canine and feline intestinal microbiota in vitro (Strompfová et al 2004, Cutrignelli et al 2009) and in vivo (Vanhoutte et al 2005, Biagi et al 2007), most of these investigations have only studied selected intestinal bacterial groups, an approach that does not fully assess the effect of probiotics and prebiotics on the intestinal microbial ecosystem. A recent study investigated the effect of a commercial preparation of probiotics and prebiotics on the faecal microbial composition of healthy cats and dogs using several molecular techniques, including a high-throughput sequencing technique (Garcia-Mazcorro et al 2011). Similarly to other studies, the authors of this investigation showed that the consumption of the formulation leads to increases in faecal abundance of the ingested microorganisms, a change that rapidly disappears 2-3 days after consumption of the preparation. Interestingly, these quantitative changes in specific bacterial groups did not seem to lead to major modifications in the overall phylogenetic composition of the fecal microbiota, as evaluated by 454-pyrosequencing. This is an interesting observation because probiotics are thought to modulate the intestinal microbiota, including other, unrelated to the ingested microorganisms, bacteria. This modulation effect of probiotics on the intestinal microbiota has also been suggested in humans, as evaluated by culture (Venturi et al 1999) and molecular techniques (Larsen et al 2011), although the results are also controversial. For example, one study showed that the consumption of a synbiotic preparation leads to changes in bacterial populations but no significant differences in fecal chemistry (Worthley et al 2009), while others propose that the intake of a synbiotic food leads to modulation of the gut metabolic activities with a maintenance of gut "biostruc- 
ture" (Vitali et al 2010). The discrepancy among different investigations may be due to the amount and types of probiotics administered (Pagnini et al 2010), as well as the combination and potential synergistic effect of different microorganisms. While some researchers encourage the design and use of several strains and/or species of microorganisms in probiotic formulations (Timmerman et al 2004), few data support a more beneficial effect of these multi-strains/species preparations compared to single strain preparations.

\section{ANTIBIOTICS}

Antibiotics are commonly used in Veterinary Medicine, but concerns have been raised about the potential reservoir of antibiotic resistance among the native intestinal microbiota of animals (Moyaert et al 2006). While in humans the effect of antibiotics on the intestinal microbiota has been characterised in depth (Dethlefsen and Relman 2011), little is known about the effect of antibiotics on the GI microbiota of cats and dogs. Johnston et al (1999) evaluated changes in duodenal bacteria of cats (n =6) during metronidazole treatment, but this study only used culture techniques. Suchodolski et al (2009) analyzed changes in the small intestinal microbiota of dogs (n $=5$ ) during administration of tylosin using 454-pyrosequencing. In this study, several changes in the abundance of different bacterial groups were observed, including an increase in the proportions of Enterococcus spp. which have been reported to be resistant to tylosin. However, these changes in bacterial amounts were not accompanied by any obvious clinical effect. Grønvold et al (2010) studied changes in faecal microbiota of healthy dogs (n = 7) during administration of amoxicilin using DGGE and qPCR. In this study, most of the variation in DGGE band profiles could be attributed to dog-specific factors, suggesting a minimal change in the composition of the fecal microbiota, as determined by the employed techniques.

\section{INHIBITORS OF GASTRIC ACID SECRETION}

Gastric acid is one of the first physiological barriers to impede the passage of potentially harmful agents into the intestinal tract. It is believed that inhibitors of gastric acid secretion can change the composition of the GI microbiota (Heidelbaugh et al 2009, Lombardo et al 2010), but only few studies support this statement and have mainly used culture techniques to study specific microorganisms (e.g. Helicobacter pylori). A recent study used a combination of several molecular techniques and concluded that the proton-pump inhibitor omeprazole can change the quantitative abundance of several gastric, duodenal and faecal microorganisms in healthy dogs, a change that did not seem to lead to major shifts in the overall phylogenetic composition of the gastric and small intestinal microbiota (Garcia-Mazcorro et al 2012a). Interestingly, the observed effect of omeprazole on the canine GI microbiota was dependent on the gender of the animals, perhaps suggesting a distinctive metabolism of the drug in male and female dogs.

\section{CONCLUDING REMARKS}

The GI tract of cats and dogs harbors a complex microbiota. The study of GI microorganisms is of interest because of its close relationship with the wellbeing of the host. Also, an increasing number of investigations suggest that GI microorganisms may play a role in the etiology of various GI disorders. However, little is known about what represents a healthy microbiota, its normal biological variations within and among individuals, and how to successfully manipulate it to prevent or treat GI disease. In order to achieve this goal, future collaborative studies should complement phylogenetic characterizations of the GI microbiota with functional (metabolic) analyses.

\section{REFERENCES}

Acinas SG, LA Marcelino, V Klepac-Ceraj, MF Polz. 2004. Divergence and redundancy of $16 \mathrm{~S}$ rRNA sequences in genomes with multiple rrn operons. J Bacteriol 186, 2629-2635.

Arciero JC, GB Ermentrout, JS Upperman, Y Vodovotz, JE Rubin. 2010. Using a mathematical model to analyze the role of probiotics and inflammation in necrotizing enterocolitis. PLoS One 5, e10066.

Armougom F, D Raoult. 2008. Use of pyrosequencing and DNA barcodes to monitor variations in Firmicutes and Bacteroidetes communities in the gut microbiota of obese humans. BMC Genomics 9, 576.

Baker GC, JJ Smith, DA Cowan. 2003. Review and re-analysis of domain-specific $16 \mathrm{~S}$ primers. J Microbiol Methods 55, 541-555.

Benno Y, H Nakao, K Uchida, T Mitsuoka. 1992. Impact of the advances in age on the gastrointestinal microflora of Beagle dogs. J Vet Med Sci 54, 703-706.

Bentley DR. 2006. Whole-genome re-sequencing. Current Opinion in Genetics \& Development 16, 545-552.

Biagi G, I Cipollini, A Pompei, G Zaghini, D Matteuzzi. 2007. Effect of a Lactobacillus animalis strain on composition and metabolism of the intestinal microflora in adult dogs. Vet Microbiol 124, 160-165.

Bik EM, PB Eckburg, SR Gill, KE Nelson, EA Purdom, F Francois, G Perez-Perez, MJ Baser, DA Relman. 2006. Molecular analysis of the bacterial microbiota in the human stomach. Proc Natl Acad Sci USA 103,732-737.

Brosey BP, RC Hill, KC Scott. 2000. Gastrointestinal volatile fatty acid concentrations and $\mathrm{pH}$ in cats. Am J Vet Res 61, 359-361.

Buddington RK. 2003. Postnatal changes in bacterial populations in the gastrointestinal tract of dogs. Am J Vet Res 64,646-651.

Caporaso JG, CL Lauber, WA Walters, D Berq-Lyons, J Hunt- 
ley, N Fierer, SM Owens, J Betley, L Fraser, M Bauer, N Gormley, JA Gilbert, G Smith, R Knight. 2012. Ultrahigh-throughput microbial community analysis on the Illumina HiSeq and MiSeq platforms. ISME J 6, 16211624.

Cave NJ, SL Marks, PH Kass, AC Melli, MA Brophy. 2006. Evaluation of a routine diagnostic fecal panel for dogs with diarrhea. J Am Vet Med Assoc 221, 52-59.

Claesson MJ, IB Jeffery, S Conde, SE Power, EM O'Connor, S Cusack, HM Harris, M Coakley, B Lakshminarayanan, O O'Sullivan, GF Fitzgerald, J Deane, M O'Connor, N Harnedy, K O'Connor, D O'Mahony, D van Sinderen, M Wallace, L Brennan, C Stanton, JR Marchesi, AP Fitzgerald, F Shanahan, C Hill, RP Ross, PW O'Toole. 2012. Gut microbiota composition correlates with diet and health in the elderly. Nature 488, 178-185.

Clapper WE, GH Meade. 1963. Normal flora of the nose, throat, and lower intestine of dogs. J Bacteriol 85, 643648 .

Cummings JH, GT Macfarlane. 1997. Role of intestinal bacteria in nutrient metabolism. Clin Nutr 16, 3-11.

Cutrignelli MI, F Bovera, R Tudisco, S D’Urso, S Marono, G Piccolo, S Calabrò. 2009. In vitro fermentation characteristics of different carbohydrate sources in two dog breeds (German sheperd and Neapolitan mastiff). J Ani Physiol Nutr 93, 305-312.

Desai AR, KM Musil, AP Carr, JE Hill. 2009. Characterization and quantification of feline fecal microbiota using cpn60 sequence-based methods and investigation of animal-toanimal variation in microbial population structure. Vet Microbiol 137, 120-128.

Dethlefsen L, DA Relman. 2011. Incomplete recovery and individualized responses of the human distal gut microbiota to repeated antibiotic perturbation. Proc Natl Acad Sci USA 108, 4554-4561.

Egert M, MW Friedrich. 2003. Formation of pseudo-terminal restriction fragments, a PCR-related bias affecting terminal restriction fragment length polymorphism analysis of microbial community structure. Appl Environ Microbiol 69, 2555-2562.

FAO/WHO, Food and Agriculture Organization/World Health Organization. 2002. Working Group Report on Drafting Guidelines for the Evaluation of Probiotics in Food. FAO/ WHO, London, UK.

Fox GE, E Stackebrandt, RB Hespell, J Gibson, J Maniloff, TA Dyer, RS Wolfe, WE Balch, RS Tanner, LJ Magrum, LB Zablen, R Blakemore, R Gupta, L Bonen, BJ Lewis, DA Stahl, KR Luehrsen, KN Chen, CR Woese. 1980. The phylogeny of prokaryotes. Science 209, 457-463.

Garcia-Mazcorro JF, JM Steiner, JS Suchodolski. 2009. Evaluation of intra-stool variability of three lactic acid bacterial genera in dogs by quantitative real-time PCR. J Vet Intern Med 23, 756-757.

Garcia-Mazcorro JF, DJ Lanerie, SE Dowd, CG Paddock, N Grützner, JM Steiner, R Ivanek, JS Suchodolski. 2011. Effect of a multi-species synbiotic formulation on fecal bacterial microbiota of healthy cats and dogs as evaluated by pyrosequencing. FEMS Microbiol Ecol 78, 542-554.

Garcia-Mazcorro JF, S Dowd, J Poulsen, JM Steiner, JS Suchodolski. 2012 ${ }^{\mathrm{a}}$. Abundance and short-term temporal variability of fecal microbiota in healthy dogs. Microbio-
logyOpen 1, 340-347.

Garcia-Mazcorro JF, JS Suchodolski, KR Jones, SC Clark-Price, SE Dowd, Minamoto Y, M Markel, JM Steiner, O Dos$\sin .2012^{\mathrm{b}}$. Effect of the proton-pump inhibitor omeprazole on the gastrointestinal bacterial microbiota of healthy dogs. FEMS Microbiol Ecol 80, 624-636.

Giannella RA, SA Broitman, N Zamcheck. 1972. Gastric acid barrier to ingested microorganisms in man: studies in vivo and in vitro. Gut 13, 251-256.

Gibson GR, KP Scott, RA Rastall. 2010. Dietary prebiotics: current status and new definition. Food Sci Technol Bull Funct Foods 7, 1-19.

Goodman AL, G Kallstrom, JJ Faith, A Reyes, A Moore, G Dantas, JI Gordon. 2011. Extensive personal human gut microbiota culture collections characterized and manipulated in gnotobiotic mice. Proc Natl Acad Sci USA 108, 6252-6257.

Grønvold AM, TM L'Abee-Lund, H Sørum, E Skancke, AC Yannarell, RI Mackie. 2010. Changes in fecal microbiota of healthy dogs administered amoxicillin. FEMS Microbiol Ecol 71, 313-326.

Hamer HM, D Jonkers, K Venema, S Vanhoutvin, FJ Troost, RJ Brummer. 2008. Review article: the role of butyrate on colonic function. Aliment Pharmacol Ther 27, 104-119.

Handl S, SE Dowd, JF Garcia-Mazcorro, JM Steiner, JS Suchodolski. 2011. Massive parallel 16S rRNA gene pyrosequencing reveals highly diverse fecal bacterial and fungal communities in healthy dogs and cats. FEMS Microbiol Ecol 76, 301-310.

Heidelbaugh JJ, KL Goldberg, JM Inadomi. 2009. Adverse risks associated with proton pump inhibitors: a systematic review. Gastroenterol Hepatol 5, 725-734.

Hellweger FL, V Bucci. 2009. A bunch of tiny individuals Individual-based modeling for microbes. Ecol Modeling 220, 8-22.

Hooper LV, AJ Macpherson. 2010. Immune adaptations that maintain homeostasis with the intestinal microbiota. Nat Rev Immunol 10, 159-169.

Hugenholtz P, BM Goevel, NR Pace. 1998. Impact of cultureindependent studies on the emerging phylogenetic view of bacterial diversity. J Bacteriol 180, 4765-4774.

Hugenholtz P, GW Tyson. 2008. Metagenomics. Nature $Q \& A$ 455, 481-483.

Huson DH, DC Richter, S Mitra, AF Auch, SC Schuster. 2009. Methods for comparative metagenomics. BMC Bioinformatics 10 (Suppl 1), S12.

Jackson CR, EE Roden, PF Churchill. 2000. Denaturing gradient gel electrophoresis can fail to separate $16 \mathrm{~S}$ rDNA fragments with multiple base differences. Molecular Biology Today 1, 49-51.

Janeczko S, D Atwater, E Bogel, A Greiter-Wilke, A Gerold, M Baumgart, H Bender, PL McDonough, SP McDonough, RE Goldstein, KW Simpson. 2008. The relationship of mucosal bacteria to duodenal histopathology cytokine mRNA, and clinical disease activity in cats with inflammatory bowel disease. Vet Microbiol 128, 178-193.

Johnston KL, AI Lamport, OP Ballèvre, RM Batt. 1999. Effects of oral administration of metronidazole on small intestinal bacteria and nutrientes of cats. Am J Vet Res 61,11061112.

Johnston KL, NC Swift, M Forster-van Hijfte, HC Rutgers, A 
Lamport, O Ballèvre, RM Batt. 2001. Comparison of the bacterial flora of the duodenum in healthy cats and cats with signs of gastrointestinal tract disease. J Am Vet Med Assoc 218, 48-51.

Klappenbach JA, JM Dunbar, TM Schmidt. 2000. rRNA operon copy number reflects ecological strategies of bacteria. Appl Environ Microbiol 66, 1328-1333.

Klein D. 2002. Quantification using real-time PCR technology: applications and limitations. Trends Mol Med 8, 257-260.

Kolmeder CA, M de Been, J Nikkilä, I Ritamo, J Mättö, L Valmu, J Salojärvi, A Palva, A Salonen, WM de Vos. 2012. Comparative metaproteomics and diversity analysis of human intestinal microbiota testifies for its temporal stability and expression of core functions. PLOS ONE 7, e29913.

Kunin V, A Engelbrektson, H Ochman, P Hugenholtz. 2010. Wrinkles in the rare biosphere: pyrosequencing errors can lead to artificial inflation of diversity estimates. Environ Microbiol 12, 118-123.

Larsen N, FK Vogensen, R Gobel, KF Michaelsen, WA AlSoud, SJ Sørensen, LH Hansen, M Jakobsen. 2011. Predominant genera of fecal microbiota in children with atopic dermatitis are not altered by intake of probiotic bacteria Lactobacillus acidophilus NCFM and Bifidobacterium animalis subsp. lactis Bi-07. FEMS Microbiol Ecol 75, 482-496.

Lee CM, CC Sieo, N Abdullah, YW Ho. 2008. Estimation of $16 \mathrm{~S}$ rRNA gene copy number in several probiotic Lactobacillus strains isolated from the gastrointestinal tract of chicken. FEMS Microbiol Lett 287, 136-141.

Lemey P, M Salemi, AM Vandamme. 2009. The Phylogenetic Handbook. Cambridge University Press, Cambridge, UK.

Liu WT, TL Marsh, H Cheng, LJ Forney. 1997. Characterization of microbial diversity by determining terminal restriction fragment length polymorphisms of genes encoding 16S rRNA. Appl Environ Microbiol 63, 4516-4522.

Lombardo L, M Foti, O Ruggia, A Chiecchio. 2010. Increased incidence of small intestinal bacterial overgrowth during proton pump inhibitor therapy. Clin Gastroenterol Hepatol 8, 504-508.

Louis P, HJ Flint. 2009. Diversity, metabolism and microbial ecology of butyrate-producing bacteria from the human large intestine. FEMS Microbiol Lett 294, 1-8.

Luo C, D Tsementzi, N Kyrpides, T Read, KT Konstantinidis. 2012. Direct comparisons of Illumina vs. Roce 454 sequencing technologies on the same microbial community DNA sample. PLoS ONE 7: e30087. doi:10.1371/journal. pone. 0030087 .

Mackay IM. 2004. Real-time PCR in the microbiology laboratory. Clin Microbiol Infect 10, 190-212.

Malinen E, T Rinttilä, K Kajander, J Mättö, A Kassinen, L Krogius, M Saarela, R Korpela, A Palva. 2005. Analysis of the fecal microbiota of irritable bowel syndrome patients and healthy controls with real-time PCR. Am J Gastroenterol 100, 373-382.

Margulies M, M Egholm, WE Altman, S Attiya, JS Bader, LA Bemben, J Berka, MS Braverman, YJ Chen, Z Chen, SB Dewell, L Du, JM Fierro, XV Gomes, BC Godwin, W He, S Helgesen, CH Ho, GP Irzyk, SC Jando, ML Alenquer, TP Jarvie, KB Jirage, JB Kim, JR Knight, JR Lanza, JH Leamon, SM Lefowitz, M Lei, J Li, KL Lohman, H Lu, VB Makhijani, KE McDade, MP McKenna, EW Myers,E
Nickerson, JR Nobile, R Plant, BP Puc, MT Ronan, GT Roth, GJ Sarkis, JF Simons, JW Simpson, M Srinivasan, KR Tartaro, A Tomasz, KA Vogt, GA Volkmer, SH Wang, Y Wang, MP Weiner, P Yu, RF Begley, JM Rothberg. 2005. Genome sequencing in microfabricated high-density picolitre reactors. Nature 437, 376-380.

Marks SL, EJ Kather, PH Kass, AC Melli. 2002. Genotypic and phenotypic characterization of Clostridium perfringens and Clostridium difficile in diarrheic and healthy dogs. $J$ Vet Inter Med 16, 533-540.

Middelbos IS, BM Veste-Boler, A Qu, BA White, KS Swanson, GC Fahey Jr. 2010. Phylogenetic characterization of fecal microbial communities of dogs fed diets with or without supplemental dietary fiber using 454 pyrosequencing. PLOS ONE 5, e9768.

Moore WEC, LV Holdeman. 1975. Discussion of current bacteriological investigations of the relationships between intestinal flora, diet, and colon cancer. Can Research 35, 3418-3420.

Moyaert H, EM De Graef, F Haesebrouck, A Decostere. 2006. Acquired antimicrobial resistance in the intestinal microbiota of diverse cat populations. Res Vet Sci 81, 1-7.

Neiger R, C Dieterich, A Burnens, A Waldvogel, I CorthésyTheulaz, F Halter, B Lauterburg, A Schmassmann. 1998. Detection and prevalence of Helicobacter infection in pet cats. J Clin Microbiol 36, 634-637.

Neiger R, KW Simpson. 2000. Helicobacter infection in dogs and cats: facts and fiction. $J$ Vet Intern Med 14, 125-133.

Nikolausz M, R Sipos, S Revesz, A Szekely, K Marialigeti. 2005. Observation of bias associated with re-amplification of DNA isolated from denaturing gradient gels. FEMS Microbiol Lett 244, 385-390.

Osbaldiston GW, EC Stowe. 1971. Microflora of alimentary tract of cats. Am J Vet Res 32, 1399-1405.

Pagnini C, R Saeed, G Bamias, KO Arseneau, TT Pizarro, F Cominelli. 2010. Probiotics promote gut health through stimulation of epithelial innate immunity. Proc Natl Acad Sci USA 107, 454-459.

Papasouliotis K, AH Sparkes, G Werrett, K Egan, EA GruffyddJones, TJ Gruffydd-Jones. 1998. Assessment of the bacterial flora of the proximal part of the small intestine in healthy cats, and the effect of sample collection method. Am J Vet Res 59, 48-51.

Pettersson E, J Lundeberg, A Ahmadian. 2009. Generations of sequencing technologies. Genomics 93, 105-111.

Preidis GA, J Versalovic. 2009. Targeting the human microbiome with antibiotics, probiotics, and prebiotics: gastroenterology enters the metagenomics era. Gastroenterology 136, 2015-2031.

Priestnall SL, B Wiinberg, A Spohr, B Neuhaus, M Kuffer, M Wiedmann, KW Simpson. 2004. Evaluation of "Helicobacter heilmannii" subtypes in the gastric mucosas of cats and dogs. J Clin Microbiol 42, 2144-2151.

Rådström P, R Knutsson, P Wolffs, M Lövenklev, C Löfström. 2004. Pre-PCR processing. Mol Biotechnol 26, 133-146.

Rajilić-Stojanović M, HGHJ Heilig, D Molenaar, K Kajander, A Surakka, H Smidt, WM de Vos. 2009. Development and application of the human intestinal tract chip, a phylogenetic microarray: analysis of universally conserved phylotypes in the abundant microbiota of young and elderly adults. Environ Microbiol 11, 1736-1751. 
Ritchie LE, JM Steiner, JS Suchodolski. 2008. Assessment of microbial diversity along the feline intestinal tract using $16 \mathrm{~S}$ rRNA gene analysis. FEMS Microbiol Ecol 66, 590-598.

Ritchie LE, KF Burke, JF Garcia-Mazcorro, JM Steiner, JS Suchodolski. 2010. Characterization of fecal microbiota in cats using universal $16 \mathrm{~S}$ rRNA gene and group-specific primers for Lactobacillus and Bifidobacterium spp. Vet Microbiol 144, 140-146.

Ritz K. 2007. The plate debate: cultivable communities have no utility in contemporary environmental microbial ecology. FEMS Microbiol Ecol 60, 358-362.

Ronaghi M, S Karamohamed, B Pettersson, M Uhlén, P Nyrén. 1996. Real-time DNA sequencing using detection of pyrophosphate release. Anal Biochem 242, 84-89.

Rothberg JM, W Hinz, TM Rearick, J Schultz, W Mileski, M Davey, JH Leamon, K Johnson, MJ Milgrew, M Edwards, J Hoon, JF Simons, D Marran, JW Myers, JF Davidson, A Branting, JR Nobile, BP Puc, D Light, TA Clark, M Huber, JT Branciforte, IB Stoner, SE Cawley, M Lyons, Y Fu, N Homer, M Sedova, X Miao, B Reed, J Sabina, E Feierstein, M Schorn, M Alanjary, E Dimalanta, D Dressman, R Kasinskas, T Sokolsky, JA Fidanza, E Namsaraev, KJ McKernan, A Williams, GT Roth, J Bustillo. 2011. An integrated semiconductor device enabling nonoptical genome sequencing. Nature 475, 348-352.

Sanger F, S Nicklen, AR Coulson. 1977. DNA sequencing with chain-terminating inhibitors. Proc Natl Acad Sci USA 74, 5463-5467.

Savage DC. 1977. Microbial ecology of the gastrointestinal tract. Annu Rev Microbiol 31, 107-133.

Schleifer KH. 2009. Classification of bacteria and archaea: past, present and future. Syst Appl Microbiol 32, 533-542.

Simpson JM, B Martineau, WE Jones, JM Ballam, RI Mackie. 2002. Characterization of fecal bacterial populations in canines: effects of age, breed and dietary fiber. Micro Ecol 44, 186-197.

Simpson KW, B Dogan, M Rishniw, RE Goldstein, S Klaessig, PL McDonough, AJ German, RM Yates, DG Russell, SE Johnson, DE Berg, J Harel, G Bruant, SP McDonough, YH Schukken. 2006. Adherent and invasive Escherichia coli is associated with granulomatous colitis in boxer dogs. Infect Immun 74, 4778-4792.

Sokol H, P Seksik, JP Furet, O Firmesse, I Nion-Larmurier, L Beaugerie, J Cosnes, G Corthier, P Marteau, J Doré. 2009. Low counts of Faecalibacterium prausnitzii in colitis microbiota. Inflamm Bowel Dis 15, 1183-1189.

Spor A, O Koren, R Ley. 2011. Unravelling the effects of the environment and host genotype on the gut microbiome. Nat Rev Microbiol 9, 279-290.

Staley JT. 2006. The bacterial species dilemma and the genomic-phylogenetic species concept. Philos Trans $R$ Soc Lond B Biol Sci 361, 1899-1909.

Stappenbeck TS, LV Hooper, JI Gordon. 2002. Developmental regulation of intestinal angiogenesis by indigenous microbes via Paneth cells. Proc Natl Acad Sci USA 99, 15451-15455.

Stecher B, WD Hardt. 2011. Mechanisms controlling pathogen colonization of the gut. Curr Opin Microbiol 14, 82-91.

Strompfová V, A Lauková, AC Ouwehand. 2004. Selection of enterococci for potential canine probiotic additives. Vet Microbiol 100, 107-114.
Suchodolski JS, CG Ruaux, JM Steiner, K Fetz, DA Williams. 2005. Assessment of the qualitative variation in bacterial microflora among compartments of the intestinal tract of dogs by use of a molecular fingerprinting technique. Am J Vet Res 66, 1556-1562.

Suchodolski JS, J Camacho, JM Steiner. 2008. Analysis of bacterial diversity in the canine duodenum, jejunum, ileum, and colon by comparative $16 \mathrm{~S}$ rRNA gene analysis. FEMS Microbiol Ecol 66, 567-578.

Suchodolski JS, EK Morris, K Allenspach, AE Jergens, JA Harmoinen, E Westermarck, JM Steiner. 2008. Prevalence and identification of fungal DNA in the small intestine of healthy dogs and dogs with chronic enteropathies. Vet Microbiol 132, 379-388.

Suchodolski JS, SE Dowd, E Westermarck, JM Steiner, RD Wolcott, T Spillmann, JA Harmoinen. 2009. The effect of the macrolide antibiotic tylosin on microbial diversity in the canine small intestine as demonstrated by massive parallel 16S rRNA gene sequencing. BMC Microbiol 9, 210.

Suchodolski JS. 2011. Intestinal microbiota of dogs and cats: a bigger world than we thought. Vet Clin North Am Small Anim Pract 41v261-272.

Suchodolski JS, ME Markel, JF Garcia-Mazcorro, S Unterer, RM Heilmann, SE Dowd, P Kachroo, I Ivanov, Y Minamoto, EM Dillman, JM Steiner, AK Cook L Toresson. 2012. The fecal microbiome in dogs with acute diarrhea and idiopathic inflammatory bowel disease. PLOS ONE 7, e51907. doi:10.1371/journal/pone.0051907.

Sunvold GD, GC Fahey, NR Merchen, GA Reinhart. 1995. In vitro fermentation of selected fibrous substrates by dog and cat fecal inoculum: influence of diet composition on substrate organic matter disappearance and short-chain fatty acid production. J Anim Sci 73, 1110-1122.

Swanson KS, CM Grieshop, EA Flickinger, LL Bauer, J Chow, BW Wolf, KA Garleb, GC Fahey. 2002. Fructooligosaccharides and Lactobacillus acidophilus modify gut microbial populations, total tract nutrient digestibilities and fecal protein catabolite concentrations in healthy adult dogs. J Nutr 132, 3721-3731.

Swanson KS, SE Dowd, JS Suchodolski, IS Middelbos, BM Vester, KA Barry, KE Nelson, M Torralba, B Henrissat, PM Coutinho, IKO Cann, BA White, GC Fahey Jr. 2011. Phylogenetic and gene-centric metagenomics of the canine intestinal microbiome reveals similarities with humans and mice. ISME J 5, 639-649.

Tap J, S Mondot, F Levenez, E Pelletier, C Caron, JP Furet, E Ugarte, R Muñoz-Tamayo, DL Paslier, R Nalin, J Dore, M Leclerc. 2009. Towards the human intestinal microbiota phylogenetic core. Environ Microbiol 11, 2574-2584.

Timmerman HM, CJ Koning, L Mulder, FM Rombouts, AC Beynen. 2004. Monostrain, multistrain and multispecies probiotics - A comparison of functionality and efficacy. Int J Food Microbiol 96, 219-233.

Tun HM, MS Brar, N Khin, L Jun, RKH Hui, SE Dowd, FCC Leung. 2012. Gene-centric metagenomics analysis of feline intestinal microbiome using 454 junior pyrosequencing. J Microbiol Methods 88, 369-376.

Van den Abbeele P, T Van de Wiele, W Verstraete, S Possemiers. 2011. The host selects mucosal and luminal associations of coevolved gut microorganisms: a novel concept. FEMS Microbiol Rev 35, 681-704. 
Van den Bogert B, WM de Vos, EG Zoetendal, M Kleerebezem. 2011. Microarray analysis and barcoded pyrosequencing provide consistent microbial profiles depending on the source of human intestinal samples. Appl Environ Microbiol 77, 2071-2080.

Vanhoutte T, G Huys, E De Brandt, GC Fahey, J Swings. 2005. Molecular monitoring and characterization of the faecal microbiota of healthy dogs during fructan supplementation. FEMS Microbiol Letters 249, 65-71.

Venturi A, P Gionchetti, F Rizzello, R Johansson, E Zucconi, P Brigidi, D Matteuzzi, M Campieri. 1999. Impact on the composition of the faecal flora by a new probiotic preparation: preliminary data on maintenance treatment of patients with ulcerative colitis. Aliment Pharmacol Ther 13, 1103-1108.

Vitali B, M Ndagijimana, F Cruciani, P Carnevali, M Candela, ME Guerzoni, P Brigidi. 2010. Impact of a synbiotic food on the gut microbial ecology and metabolic profiles. $B M C$ Microbiol 10, 4.

Wilkins MR, JC Sanchez, AA Gooley, RD Appel, I HumpherySmith, DF Hochstrasser, KL Williams. 1996. Progress with proteome projects: why all proteins expressed by a genome should be identified and how to do it. Biotechnol Genet Eng 13, 19-50.
Worthley DL, RK Le Leu, VL Whitehall, M Conlon, C Christophersen, D Belobrajdic, KA Mallitt, Y Hu, N Irahara, S Ogino, BA Leggett, GP Young. 2009. A human, doubleblind, placebo-controlled, crossover trial of prebiotic, probiotic, and synbiotic supplementation: effects on luminal, inflammatory, epigenetic, and epithelial biomarkers of colorectal cancer. Am J Clin Nutr 90, 578-586.

Xenoulis PG, B Palculict, K Allenspach, JM Steiner, AM Van House, JS Suchodolski. 2008. Molecular-phylogenetic characterization of microbial communities imbalances in the small intestine of dogs with inflammatory bowel disease. FEMS Microbiol Ecol 66, 579-589.

Yang X, L Xie, Y Li, C Wei. 2009. More than 9,000,000 unique genes in human gut bacterial community: estimating gene numbers inside a human body. PLoS One 4, e6074.

Zoetendal EG, K Ben-Amor, AD Akkermans, T Abee, WM de Vos. 2001. DNA isolation protocols affect the detection limit of PCR approaches of bacteria in samples from the human gastrointestinal tract. Syst Appl Microbiol 24, 405-410.

Zoetendal EG, CT Collier, S Koike, RI Mackie, HR Gaskins. 2004. Molecular ecological analysis of the gastrointestinal microbiota: a review. J Nutr 134, 465-472.

Zuckerkandl E, L Pauling. 1965. Molecules as documents of evolutionary history. J Theor Biol 8, 357-366. 